\title{
Antibacterial Activity of Plant Lectins: a Review
}

\author{
Nathália Regina Galvão Silva ${ }^{1}$ \\ https://orcid.org/0000-0002-0818-8349
}

\section{Francielly Negreiros de Araújo²* \\ http://orcid.org/0000-0002-7631-7077}

${ }^{1}$ Federal University of Pernambuco, Department of Biochemistry, Recife, Pernambuco, Brazil; ${ }^{2}$ Federal University of Pernambuco, Department of Genetics, Recife, Pernambuco, Brazil.

Editor-in-Chief: Paulo Vitor Farago

Associate Editor: Jane Manfron Budel

Received: 2020.10.01; Accepted: 2021.02.24.

${ }^{*}$ Correspondence: franciellyng@hotmail.com; Tel.: +55-83-996554026 (F.N.A.).

\section{HIGHLIGHTS}

- Plant lectins are proteins that have biotechnological potential.

- The antibacterial activity of lectins can occur by immunomodulation.

- Due to their characteristics, lectins are promising targets for antibacterial activity.

\begin{abstract}
Lectins are proteins that form a heterogeneous group, capable of binding specifically and reversibly to carbohydrates. They occur in various types of organisms, having different functions, in plants they are present in almost all structures, however with greater proportion in seeds roots and rhizomes. This review aims to provide a more detailed understanding of the antibacterial action of lectins and their biotechnological potential against pathogenic bacteria in the last ten years. Several mechanisms of action are described for the antibacterial activity of these proteins among which the best known occurs due to the interaction between the binding site of the lectin and the carbohydrates exposed on the bacterial cell surface. In vivo studies demonstrate that lectins act on the cascade of cytokines and influencing the level of nitric oxide as ways to decrease bacterial infection. To date, lectins have performed a wide antibacterial activity, emphasizing that each lectin acts according to its carbohydrate specificity, in this way, it is possible to have a distinct performance according to the plant species that are extracted. Thus, being an alternative to the antibacterial resistance that occurs in response to antibiotics. Furthermore, more studies with this theme are necessary for clinical application.
\end{abstract}

Keywords: proteins; biological activity; antibiotics.

\section{INTRODUCTION}

Lectins are a group of heterogeneous proteins, able to establish specific and reversible bonds with monosaccharides and oligosaccharides, being free or bound to the cell surfaces by the specific binding sites [1,2]. The carbohydrate binding site allows lectins to behave as recognition molecules, being found in various organisms, including animals, fungi, viruses, bacteria and distributed in various plant organs and tissues [3]. Plants are considered the most accessible source of proteins, being possible to extract and isolate proteins from the entire anatomy, including seeds, barks, leaves, fruits, roots and tubers [2]. 
Plant lectins can be divided into two large groups according to gene expression and induction pattern, that constitutively expressed and regulated during development, and the lectins with low level of expression and activated by means of induction. Tissues that present higher levels of expression and consequently higher protein concentration such as seeds and vegetative storage tissues have always been major targets for the extraction and isolation. However, from the search for new lectins, have been extracted proteins from tissues with low levels of expression, such as leaves, roots and flowers. Resulting in the discovery of new lectins that have expression induced by biotic and abiotic stress factors [4].

Studies describe different activities related to plant lectin that have economic importance for agriculture, such as its use as bioinsecticides, binding to glycan's present in the insects and interfering in physiological processes such as: time of development, coloration, feeding, adult fecundity and mortality, demonstrating a high potential for the development of new pest control strategies [5]. The lectin also acts as an intermediary for symbiosis between the plant and nitrogen fixing bacteria [6-9].

Besides its agricultural importance, also arouses clinical interest due activities such as antinociceptive , anti-inflammatory and antihemolytic activity [10-12], healing of cutaneous wounds [13], control of the metastatic potential of tumor cells through mechanisms induces anti-angiogenic activity and apoptosis [14$16]$, anti-inflammatory activity due to the ability to inhibit the neutrophil migration and to reduce IL1- $\beta$ and TNF- $\alpha$ levels [17], immunomodulatory effect, NO production [18,19], induction of mitosis [20], cytokine production in vitro and in vivo [21] and antifungal action [22-24].

In addition to the biological activities that have been cited, the lectins also have antibacterial activity, which is the focus of this article. These proteins may be listed as optimal candidates for the treatment of infections caused by bacteria [25-27], since its carbohydrate binding properties are able to establish interactions with pathogenic cells, promoting inhibition of microbial adhesion [28]. Thus, this review aims to provide a more detailed understanding of the antibacterial action of lectins and their biotechnological and pharmaceutical potential in the fight against pathogenic bacteria in the last ten years.

To reach the proposed objective, a search was carried out in the databases (ScienceDirect; PubMed; ScieLo; LILACS; Scopus; SpringerLink; PLoS and Hindawi) regarding the articles in the period from 2011 to 2020, for this purpose the descriptors were used: lectin, antibacterial, biological activity and antimicrobin.

\section{Antimicrobial activity of plant lectins as an alternative to antibiotic resistence}

\section{Mechanism of action}

A structural characteristic of the lectin is its site for binding to carbohydrates, which has a fundamental function for antimicrobial activity, considering that almost all microorganisms express carbohydrates on the cell surface, each polysaccharide is a potential binding site for lectin [29]. With this, the effectiveness of this protein in the antibacterial activity became possible. Gram-negative bacteria have lipopolysaccharides (Figure 1) on their surface and Gram-positive possess peptidoglycan, teichoic and teichuronic acids (Figure 2), the binding specificity carbohydrate with lectins is achieved through hydrogen bridges, van der Waals and hydrophobic interactions between sugar and lectin site [30]. When antibacterial activity is brought into focus, the most known mechanism of action is what involves the binding of the lectin to the carbohydrates exposed on the outer membrane or cell wall of the bacteria, forming a channel in the cell membrane and thus inducing its target to apoptosis with the exit of intracellular components [31-34]. By electron microscopy it was proven that the conformational change in the membrane may result in the formation of a pore [35], which leads to an increase in bacterial permeability, allowing the leakage of intracellular proteins. However studies with the Moringa oleifera seed lectin (WSMoL) presented that this effect occurred in a general way, that is, even in the bacteria that WSMoL had no antibacterial effect, cell wall integrity was lost, promoting increased permeability and, consequently, the release of intracellular proteins [36].

The specific carbohydrate for each lectin may influence its biological activity, and its antibacterial effect is linked to the result of the interaction between lectin and its specific receptors on the cell membrane. Due to interact with bacterial membrane receptors, the lectin leads to a change in cellular metabolism of the bacteria by inducing conformational changes. For example, $\mathrm{N}$-acetylglucosamine is present on the cell wall of different bacteria, the lectin ApulSL has specificity for this carbohydrate, thus its antibacterial activity is attributed to its specificity of binding to the residues of the $\mathrm{N}$-acetylglucosamine [37]. The structural difference between Gram-negative and Gram-positive bacteria can lead to a different antibacterial activity, because it is more complex for the lectin to cross the outer membrane and cell wall of a Gram-negative strain to finally reach the periplasmic space, in contrast the high level of peptidoglycan that is expressed by the Gram-positive bacteria, provides more sites of interaction with the lectin [38]. 


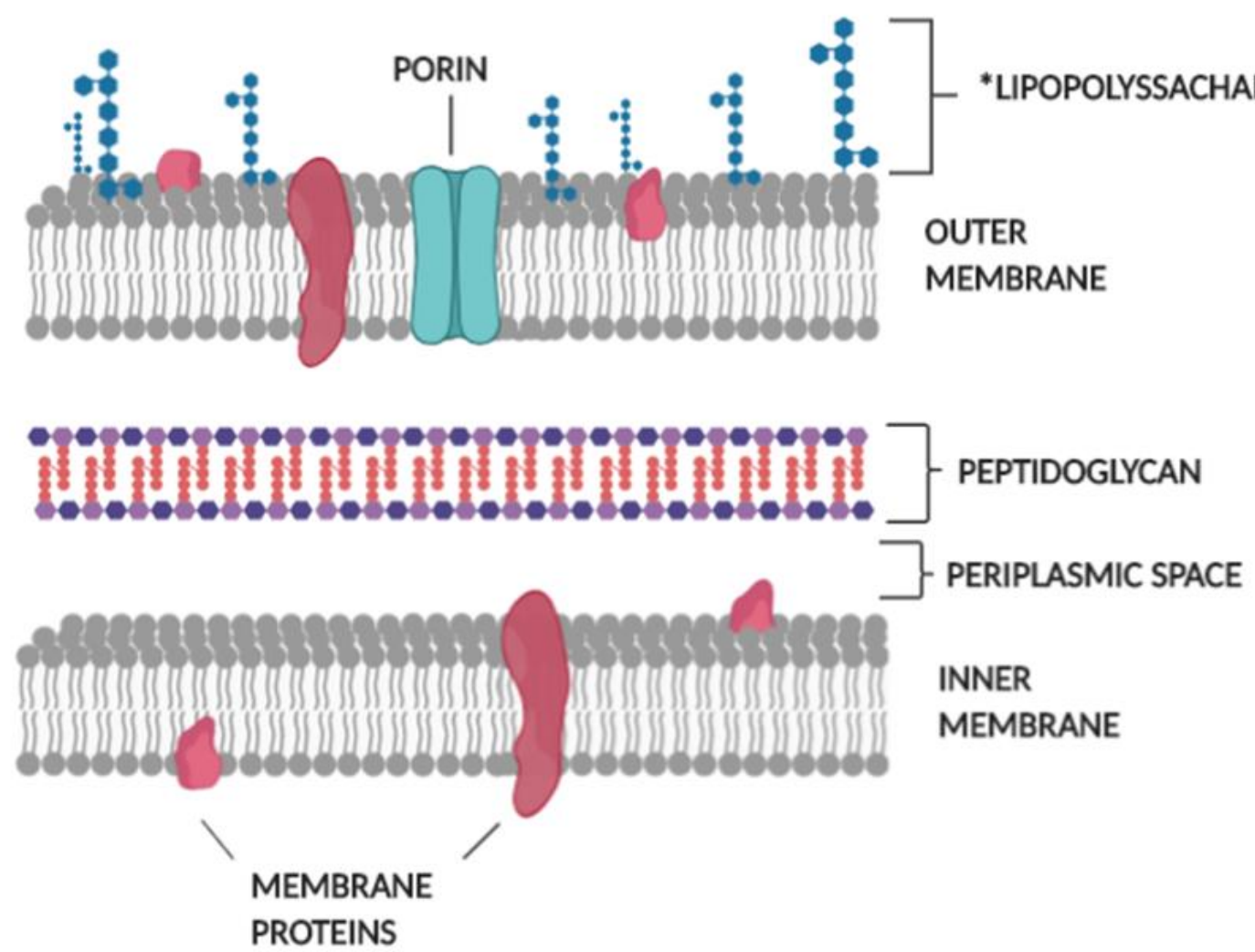

Figure 1. Scheme of a cell wall structure of Gram-negative bacteria. ${ }^{*}$ The carbohydrate residues that may be the binding target of antimicrobial lectins.

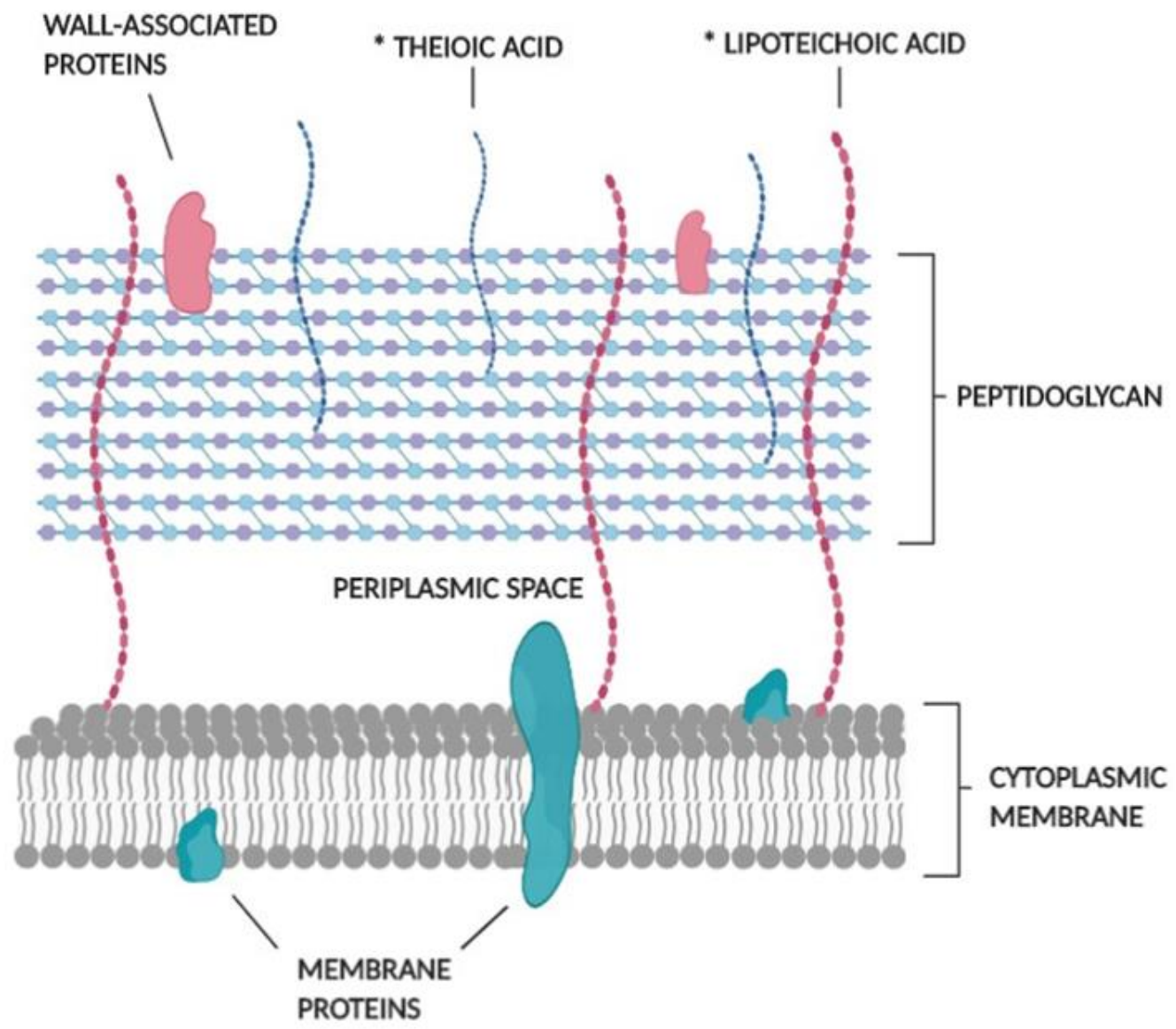

Figure 2. Scheme of a cell wall structure of Gram-positive bacteria. ${ }^{*}$ The carbohydrate residues that may be the binding target of antimicrobial lectins. 
Some oral pathogenic bacteria have a mechanism of adhesion on the surface of the tooth through the secretion of several extracellular polysaccharides [39]. The mechanism of action for oral bacteria has not yet been well elucidated. Although, the lectin BVL-I inhibited bacteria such as Streptococcus mutans and Streptococcus sanguins, possibly through the binding with the carbohydrate that would be used for bacterial adhesion on the surface of the tooth or in direct connection with the components of the capsule, covering the bacterial surface [39].

Another mechanism of antibacterial action associated with lectin occurs through antibiofilm activity, acting as an anti-QS molecule. The quorum-sensing (QS) process occurs in an interspecies or intraspecies manner. The bacteria produce and release chemical signaling molecules, which are called auto-inducers, the concentration of such molecules increases proportionally to the density of the cell population. When the concentration of the autoinducers reaches the appropriate level, changes occur in molecular and cellular components, such as gene expression [40]. The bacterial QS allows a certain group of cells to regulate their gene expression evenly. This process is relevant for the production of bioluminescence, formation of biolfilm, gene exchange, expression of virulence factor $[41,42]$.

The biofilm is a sessile organization, made up of cells and a matrix, which is self-produced and formed by extracellular polymer substances [43]. Biofilms are fundamental in the research for antibacterial activity, considering that they are responsible for $80 \%$ of microbial infections and have high resistance to antibiotics [43]. To have an effect on biofilm development, one of the mechanisms adopted is the interruption of QS signaling. This and other anti-QS mechanisms have been described for lectins. An example of plant lectin with anti-QS activity is the ConM, extracted from Canavalia maritima, which has been able to reduce the expression of genes related to biofilm production in strains of Streptococcus mutans, as well as genes related to resistance to antibiotics [44].

The mechanism of action may not be directly related to the bacteria, the lectins ConBr and CFL were unable to inhibit the growth in vitro of the Salmonella typhimurium strain, however, in vivo tests was made daily administration of both lectins for 3 days in infected mice, and there was a survival rate of $90 \%$ for CFL and $100 \%$ for $\mathrm{ConBr}[45]$.

How can occur activity in vivo and not occur in vitro? Before the question be elucidated it is necessary to understand that the early infection by Salmonella provides that the cytokine IL-12 stimulates the release of INF-y that is derived from natural killers (NK) cells, this mechanism triggers the activation of macrophages to combat the pathogen [46,47]. But, in a bacterial septic shock occurs an overproduction of pro-inflammatory cytokines (IL -1 e TNF $-\alpha$ ) [47]. With this, the lectin does not act directly with the bacteria, but in the cascade of cytokines. When administered lectins in mice, a low regulation of IL-1 was observed for CFL, IL - 10 and TNF - a for ConBr, also occurred a decrease of the levels of nitric oxide (NO) [45].

The immunomodulatory lectins the release of inflammatory cytokines and nitric oxide in the immune system, this way is able to reduce the bacterial load in the affected organs and increase the survival rate [48], the importance of this mechanism of action can be viewed when it is understood, for example, that IL10 and NO are events induced by lipopolysaccharide which is a carbohydrate present in the bacterial outer membrane. This class of protein during a bacterial infection manages to recruit leukocytes into the infectious focus and can recognize receptors in T lymphocytes induce them to mitogenic activation and differentiation in T helper lymphocyte subtypes (Th1, Th2 e Th17) [20], this event promotes maturation of macrophages and dendritic cells. Another important mechanism of immunological action that has been reported with the use of CFL and ConBr lectin was the possibility of reducing leukopenia, considering that, the Salmonella infection can lead the individual to a state of immunosuppression [45].

\section{Antibacterial resistance}

Antibiotics are natural or synthetic substances that are intended for use in treating infections in humans and animals, usually from bacteria. The discovery and production of antibiotics is one of the greatest achievements in medicine, which has helped to reduce the mortality rate in medical practice in hospitals around the world [49]. Currently, it can be found the indiscriminate and large-scale use of this substance to increase production in agriculture, aquaculture and livestock. It can also be used in the treatment of water or even by society in a wrong way [50,51]. This misuse of antibiotics is the primary factor in the selection and dissemination of resistant bacteria that will infect humans and animals [52]. Since antibiotics normally used for treatment against bacterial infections are no longer effective, it is necessary to resort to other options that are called 'reserve' or 'last resort', which are numerous times expensive and may have toxic preparations [53]. 
The cell wall of Gram-positive bacteria is fundamental for the chemical and mechanical integrity of the bacterial cell, having as its primary component the peptidoglycan, which has the biosynthesis determined by different proteins and is responsible for cell rigidity and protection. In this way the cell wall becomes a common target of many antibiotic drugs. Mechanisms of cell wall inhibition may act differently, for example the fosfomycin which inhibits the synthesis of peptidoglycan, and penicillin that prevents the cross-linking between peptides. Antibiotics such as chloramphenicol may act also inhibiting the synthesis of cytoplasmic proteins [52]. The mechanism of bacterial inhibition presented by lectins is distinguished from those presented by antibiotics [54], due to the formation of a pore in the bacterial membrane, allowing leakage of the intracellular content [55]. Because of this scenario, the search for new alternatives is of paramount importance.

\section{Antibacterial activity of plant lectins}

Over the years the plants have been used to prepare teas and extracts that are used in popular medicine for the prevention and treatment of diseases, the most reported activity is the antimicrobial action. The antimicrobial activity of plant products and the ease in obtaining its compounds has been shown to be a good source of studies to obtain new antibiotics [56]. The prospection of compounds with pharmacological applications has been gaining prominence, because of the search for more viable alternatives to treat infections. During the last eight years several authors have described antibacterial activities of lectins extracted from plant species (Table 1).

Archidendron jiringa is a leguminous that belongs to the Fabaceae family, it's found in Indonesia, Malaysia and Thailand, is used as different resources such as food flavoring, medicines, handmade wood and firewood. The antibacterial activity of the lectin present in the seeds of $A$. jiringa inhibited the straws Staphylococcus aureus and Bacillus subtilis, while the results for Gram-negative bacteria such as Escherichia coli and Pseudomonas aeruginosa were not as satisfactory, indicating a more significant inhibitory activity against Gram-positive bacteria, probably due to the binding of the lectin to the muramic acid and $\mathrm{N}$-acetylmuramic acid, which are carbohydrates present mainly in the cell wall of Gram-positive bacteria. The results propose that this protein acts directly in the defense of the plant against pathogens, since the great majority of the microorganisms express surface carbohydrates and these become potential targets for the performance of the lectins. The carbohydrate binding site probably plays the role of recognition of bacteria [29]. 
Table 1. Bacterial activity of plant lectin in the period from 2011 to 2020.

\begin{tabular}{|c|c|c|c|c|c|}
\hline Plant species $^{a}$ & $\begin{array}{l}\text { Family of plant } \\
\text { species }\end{array}$ & $\begin{array}{l}\text { Name of } \\
\text { lectin }\end{array}$ & $\begin{array}{l}\text { Carbohydrate } \\
\text { ligands }\end{array}$ & Antibacterial activity & Reference \\
\hline $\begin{array}{l}\text { Archidendron } \\
\text { jiringa }\end{array}$ & Fabaceae & ND & ND & $\begin{array}{l}\text { S. aureus, B. subitilis, E. coli } \\
\text { and } P \text {. aeroginosa }\end{array}$ & [29] \\
\hline $\begin{array}{l}\text { Schinus } \\
\text { terebinthifolius }\end{array}$ & Anacardiaceae & SteLL & $\begin{array}{c}\mathrm{N}- \\
\text { acetylglucosamine }\end{array}$ & $\begin{array}{l}P . \text { mirabilis, E. coli, } S . \\
\text { aureus, } K . \text { pneumoniae, } S . \\
\text { enteritidis and } P . \text { aeroginosa }\end{array}$ & [38] \\
\hline $\begin{array}{l}\text { Artocarpus } \\
\text { heterophyllus, } \\
\text { Canavalia } \\
\text { ensiformis, } \\
\text { Lens culinaris } \\
\text { and Pisum } \\
\text { sativum }\end{array}$ & $\begin{array}{l}\text { Moraceae; } \\
\text { Fabaceae; } \\
\text { Fabaceae; } \\
\text { Fabaceae. }\end{array}$ & ND & ND & $\begin{array}{c}\text { B. subitilis, } P \text {. aeroginosa, E. } \\
\text { coli and } S \text {. aureus }\end{array}$ & [57] \\
\hline $\begin{array}{l}\text { Indigofera } \\
\text { heterantha }\end{array}$ & Fabaceae & $\mathrm{IHL}$ & $\begin{array}{l}\text { D-galactose, D- } \\
\text { mannose and D- } \\
\text { arabinose. }\end{array}$ & $\begin{array}{l}\text { K. pnuemoniae, S. aureus, } \\
\text { E. coli and B. subtilis }\end{array}$ & [55] \\
\hline $\begin{array}{l}\text { Cratylia } \\
\text { floribunda }\end{array}$ & Fabaceae & CFL & ND & S. aureus and S. epidermidis & [58] \\
\hline $\begin{array}{l}\text { Vatairea } \\
\text { macrocarpa; } \\
\text { Bauhinia } \\
\text { bauhinioides }\end{array}$ & Fabaceae & VML, BBL & ND & $\begin{array}{l}\text { S. aureus, S. epidermidis, } \\
\text { and } P \text {. aeruginosa }\end{array}$ & [58] \\
\hline $\begin{array}{l}\text { Euphorbia } \\
\text { helioscopia }\end{array}$ & Euphorbiaceae & EHL & Fructose & $\begin{array}{l}\text { K. pneumoniae, } P \text {. } \\
\text { aeruginosa and E. Coli }\end{array}$ & [51] \\
\hline $\begin{array}{l}\text { Tinospora } \\
\text { tomentosa } \\
\text { Miers }\end{array}$ & $\begin{array}{c}\text { Menispermace } \\
\text { ae }\end{array}$ & TTML & Lactose & $\begin{array}{l}\text { V. mimicus, S. aureus, } \\
\text { Bacillus cereus, S. typhi, } \\
\text { and S. dysenteriae }\end{array}$ & [59] \\
\hline $\begin{array}{l}\text { Kaempferia } \\
\text { rotunda Linn }\end{array}$ & Zingiberaceae & KRL & ND & S. aureus and E. coli & [03] \\
\hline $\begin{array}{c}\text { Moringa } \\
\text { oleifera }\end{array}$ & Moringaceae & WSMoL & ND & $\begin{array}{c}\text { Bacillus sp., B. pumillus, } \\
\text { P. stutzerie } S . \\
\text { marcescens }\end{array}$ & [36] \\
\hline $\begin{array}{l}\text { Chenopodiu } \\
\text { m quinoa }\end{array}$ & Amaranthaceae & CqLec & $\begin{array}{l}\text { Glucose and } \\
\text { mannose }\end{array}$ & $\begin{array}{l}\text { E. coli, } P \text {. aeruginosa } \\
\text { and } S \text {. enterica }\end{array}$ & [60] \\
\hline $\begin{array}{c}\text { Broccolini } \\
\text { (Brassica } \\
\text { oleracea } \\
\text { Italica } x \\
\text { Alboglabra) }\end{array}$ & Brassicaceae & BL & $\begin{array}{l}\text { D-mannose and } \\
\text { arabinose }\end{array}$ & $\begin{array}{l}\text { H. pylori, S. dysenteriae, } \\
\text { P. aeruginosa, E. coli, } \\
\text { and S. aureus }\end{array}$ & [61] \\
\hline $\begin{array}{l}\text { Bauhinia } \\
\text { variegata }\end{array}$ & Fabaceae & BVL-I & $\begin{array}{l}\text { Galactose and N- } \\
\text { acetylgalactosami } \\
\text { ne (GalNAc) }\end{array}$ & $\begin{array}{l}\text { S. mutans and } S . \\
\text { sanguins }\end{array}$ & [39] \\
\hline $\begin{array}{l}\text { Calliandra } \\
\text { surinamensis }\end{array}$ & Fabaceae & CasuL & $\begin{array}{l}\text { Mannose and } \\
\text { glucose }\end{array}$ & $\begin{array}{l}\text { S. saprophyticcus and } \\
\text { S. aureus }\end{array}$ & [21] \\
\hline
\end{tabular}


Euphorbia antiquorum $\mathrm{L}$

Euphorbiaceae

EantH

Galactose and Nacetylmuramic acid

Jacalin $^{b}$

ND

heterophyllus

Moraceae

arietinum $\mathrm{L}$

Fabaceae

CAL

ND

ApuL

ND

Alpinia
purpurata

Portulaca

Portulacaceae

Parkia

platycephala

Punica

granatum

Punicaceae

PgTeL

ND

Galactose,glucose , N-

acetylglucosamine

(GlcNac)

ND

Punica

granatum

Punicaceae

PgTeL

ND

ND
Escherichia coli

Drug-resistant

Escherichia coli isolates able to produce $\beta$ lactamases

Methicillin resistant

Staphylococcus aureus

e Staphylococcus epidermidis, Streptococcus agalactiae,

Propionibacterium acnes and Salmonella typhimurium.

Methicillin resistant Staphylococcus aureus (MRSA), E. coli, Aeromonas hydrophila, Bacillus subtilis and $S$. aureus.

Escherichia coli, Bacillus subtilis, Serratia marcescens and Pseudomonas aeruginosa.

Non-resistant and oxacillin-resistant isolate of Staphylococcus aureus and multidrugresistant isolate of Pseudomonas aeruginosa.

Enterococcus faecalis, Pseudomonas aeruginosa and Staphylococcus aureu Staphylococcus aureus (MRSA)

Enterococcus faecalis, Micrococcus luteus, Klebsiella pneumoniae, Serratia sp. 
a Plant species from which lectins were extracted; ${ }^{b}$ Biological activity was performed with lectin combined with copper sulfide nanoparticles; ${ }^{c}$ Synergistic activity of lectin combined with Gentamycin; ND: There is no information in the paper

Schinus terebinthifolius is a tree popularly known as Brazilian pepper, is commonly used in popular medicine for preparation of infusions to treat infections in the respiratory, digestive and urinary tract, rheumatism and oral candidiasis. The antibacterial assays performed with the lectin of $S$. terebinthifolius (SteLL) demonstrated a bactericidal activity against the strains Proteus mirabilis, E. coli, and $S$. aureus, and for Klebsiella pneumoniae, Salmonella enteritidis and $P$. aeruginosa it was obtained a bacteriostatic activity [38]. A bactericidal activity is defined by a reduction of $\geq 99.9 \%$ in viable bacterial density in an 18-24-h period while the bacteriostatic activity is characterized as a ratio of minimal bactericidal (MBC) to minimal inhibitory (MIC) of $>4$ [38]. The physical-chemical stability of the lectin is a fundamental characteristic for its application as an alternative to the antibiotic, since antimicrobial agents must remain active over a wide range of temperature and $\mathrm{pH}$. The hemagglutinating activity of SteLL did not change in the presence of divalent cations, the lectin is structurally stable and active at temperatures and $\mathrm{pH}$ similar to that found in the human body $\left(37^{\circ} \mathrm{C}, \mathrm{pH} 6.5-7.5\right)$, suggesting its potential application in the treatment of infectious diseases [38]. Nair and coauthors. [57], analyzed the antibacterial activity of partially isolated lectins of the species Artocarpus heterophyllus, Canavalia ensiformis, Lens culinaris and Pisum sativum by the disk diffusion method. The lectins showed activity for $B$. subitilis, $P$. aeruginosa, $E$. coli and $S$. aureus, obtaining results similar to those presented by SteLL lectin.

Indigofera heterantha is a member of the Leguminoseae family, found in regions of the Himalayas. The lectin of $I$. heterantha is a tetramer having a molecular weight of about $70 \mathrm{kDa}$. The lectin IHL showed effective antibacterial action against four strains, K. pneumoniae, $S$. aureus, $E$. coli and $B$. subtilis. The physico-chemical characterization showed that IHL maintains structural stability in the range of $\mathrm{pH} 2$ to 9 , indicating that the amino acids which composes the protein are not easily altered by variations in $\mathrm{pH}$, the thermal stability was established around $90^{\circ} \mathrm{C}$. Indicating $\mathrm{IHL}$ as a source of relevant information for clinical microbiology and potential therapeutic applications [55]

Studies with CFL, VML and BBL plant lectins extracted from Cratylia floribunda, Vatairea macrocarpa and Bauhinia bauhinioides respectively, tested these proteins inhibition capacity against pathogenic bacteria and biofilm formation. The lectin CFL demonstrated activity in reducing the growth of bacteria Staphylococcus epidermidis, S. aureus and biomass reduction in biofilms [58].

The biofilm formation is related to a higher frequency of mutations and resistance to antibiotics, associating with more persistent bacterial infections. The antibiofilm effect presented by lectins may be related to the ability of these proteins to bind to the polysaccharides of bacterial cell walls, inhibiting cell adhesion in surfaces and among bacterial cells, and reducing bacterial cell viability, by interfering in the expression of genes related to biofilm formation, which may affect the biofilm structure [59].

Lectins with specific affinity for D-galactose (VML and BBL) showed activity against $S$. aureus, $S$. epidermidis, and $P$. aeruginosa. The ability of different types of lectins to present different biological activities is associated with their specificity, which may interact with different bacterial compounds such as teichoic and teichuronic acids, peptidoglycans and lipopolysaccharides.

The Euphorbia helioscopia has cosmopolitan distribution, belongs to the family Euphorbiaceae and is traditionally used in prevention and treatment of diseases such as ascites, edemas and tuberculosis. It was extracted from its leaves the lectin EHL with molecular weight of $65 \mathrm{kDa}$, characterized by having fructose binding specificity, this lectin demonstrated to be capable of inhibiting bacterial growth of K. pneumoniae, $P$. aeruginosa and E. coli[51].

The lectin CqLec was extracted from seeds of Chenopodium quinoa, a pseudo cereal very nutritious used in food, by SDS-PAGE it was observed that the lectin is composed of two subunits with weights of 25 and $35 \mathrm{kDa}$, respectively, the CqLec shows specificity for glucose and mannose, in experiments performed showed inhibitory activity against Gram-negative bacteria specifically E. coli, $P$. aeruginosa and Salmonella enterica. With this it is possible to infer that the result of the bacterial inhibition is because they have in their LPS composition one or more of the sugars to which CqLec has specificity [60].

Broccolini is a hybrid from the species Brassica oleracea Italica and Alboglabra is a green vegetable similar to broccoli but with smaller florets and longer and thin stalks, from this plant was extracted the lectin $\mathrm{BL}$ of $27 \mathrm{kDa}$, with specificity for mannose and arabinose. The BL showed inhibition against Helicobacter pylori, Shigella dysenteriae, $P$. aeruginosa, E. coli, and S. aureus, being H. pylori more strongly inhibited, the result is also attributed to the specificity of the lectin for the carbohydrate mannose [61]. 
Using the lectin TTML, isolated from the plant Tinospora tomentosa Miers, that is widely used by Indian medicine as antipyretic, analgesic and anti-inflammatory, it was obtained activity against the bacteria Vibrio mimicus, S. aureus, B. cereus, Salmonella typhi, and Shigella dysenteriae [62].

The interaction between lectins and bacteria is confirmed by the agglutination of the bacterial cells, which occurs probably due the binding of the lectins to the carbohydrates exposed on the bacterial surface. The lectin KRL extracted from rhizomes of the plant Kaempferia rotunda Linn, with molecular weight of 29 $\mathrm{kDa}$, demonstrated activity against $S$. aureus and $E$. coli. Two different levels of inhibition were obtained, one with a lower percentage of inhibition, presenting bacteriostatic activity and the other one with greater activity, being characterized as bactericide [3].

From the plant Moringa oleifera was isolated a lectin named WSMoL, which presents affinity with $\mathrm{D}(+)$ - fructose. In addition to the inhibitory activity against Bacillus sp., Bacillus pumillus, Pseudomonas stutzeri and Serratia marcescens the WSMoL was also able to agglutinate bacterial cells, being this phenomenon disrupted after the addition of the monosaccharide fructose. Bacterial cells that were treated with WSMoL were visualized as individual clusters of small dispersions, this result indicates that the lectin was able to interact with biofilm formation. All the bacteria tested showed leakage of proteins, even those that WSMoL did not obtain bactericidal activity, consequently, the data suggest that the lectin increasing the membrane permeability and allowing the passage of proteins, which may be due to the pores that the lectin can form in the bacterial membrane [59]. The same lectin in another study also showed bacteriostatic and bactericidal activity against E. faecalis, K. pneumoniae and Serratia sp., But only bacteriostatic for M. luteus. The Gram-negative bacteria, K. pneumoniae and Serratia sp., Incubated with WSMoL showed a significant decrease in extracellular protease activity. Bacterial proteases have a great potential to provide pathogenesis, they degrade structural and functional proteins of human tissue, as well as proteins involved in the immune system. The lectin obtained better results with Gram-negative bacteria, which raises the hypothesis that WSMoL binds to lipopolysaccharide (LPS) [63].

The lectin BVL-I was isolated from seeds of the plant Bauhinia variegata, it is presented as a single chain lectin specific for Galactose/N-acetylglucosamine (Gal/GalNac) with molecular weight of $32 \mathrm{kDa}$. It has been used in the inhibition of bacterial adhesion and in the healing of damaged epithelial tissue. The study of this lectin has as differential the fact that the source of the protein is limited, and then produced on a large scale through gene expression and cloning techniques, although expressed as a monomer, continued to obtain the same biological activity which was able to impair the initial adhesion of $S$. mutans and Streptococcus sanguins. Being an alternative for the production of a large scale isolate with biological activit [39].

The lectin ApulSL was extracted and isolated from seeds of a plant of Brazilian caatinga of the species Apuleia leiocarpa, this lectin is characterized as a disordered protein by having tyrosine in its structure with a highly hydrophobic nucleus. Its hemagglutinating activity proved to be resistant even after $100^{\circ} \mathrm{C}$ and dependent on $\mathrm{Mg}$, being inhibited by $\mathrm{N}$-acetylglucosamine, $\mathrm{D}(-)$ arabinose, and azocasein, which demonstrates affinity for these carbohydrates. The ApuISL showed inhibition of the growth of the bacteria: Bacillus cereus, Bacillus subtilis, Enterococcus faecalis, Micrococcus luteus, Streptococcus pyogenes, S. aureus, Xanthomonas campestris pv. campestris, Xanthomonas campestris pv. viticola, Xanthomonas campestris pv. malvacearum, K. pneumoniae, E. coli, P. aerugionosa and Salmonella enteritidis. The inhibition was more effective for the three species of Xanthomonas, for Xanthomonas campestris $p v$. campestris was obtained the lowest MIC, which reached $12.5 \mu \mathrm{g} / \mathrm{mL}$ [37]. As ApulSL, bracts lectin extracted from the same species (ApuL) showed bacteriostatic activity against $S$. aureus strains not resistant and oxacillin-resistant isolate, the minimum inhibitory concentration was 50 and $400 \mathrm{ug} / \mathrm{ml}$. The lectin promoted minor damage to cell membrane of non-resistant $S$. aureus, however ApuL bacterial induced cell cycle arrest, given that some cells do not appear to have completed the cell division. On the other hand, against the lectin-resistant isolate it did not cause serious damage to the membrane, but the cells showed prominences on their surfaces without cellular morphological alteration, which demonstrates that ApuL can promote inhibition and impair the cell viability through different mechanisms. The combination of ApuL-oxaxiline showed a synergistic effect against resistant strains [64].

The lectin extracted from leaves of Calliandra surinamensis, was isolated and named CasuL, is characterized as an acidic protein of $48 \mathrm{kDa}$, being an oligomeric protein composed of three subunits. The degree of toxicity of CasuL was evaluated, which showed no reduction in the viability of human blood mononuclear cells, this evaluation of the cytotoxicity of lectins is fundamental, as it is known that this type of protein may be toxic to mammals, in this way, the result of CasuL indicates that it may be a potential target for studies of biological activities in vivo. In its antibacterial activity, it had bacteriostatic effect for 
Staphylococcus saprophyticus and $S$. aureus, the antibiofilm activity was more significant than inhibition of bacterial growth, especially for $S$. saprophyticus, which shows that CasuL has a potential that needs evaluation to be used to cover surfaces [21].

EantH lectin, purified from Euphorbia antiquorum latex, has an affinity for galactose and $\mathrm{N}$ acetylmuramic acid present in the cell walls of bacteria. This lectin has antibacterial activity for Staphylococcus aureus and Staphylococcus epidermidis (MIC of $2000 \mu \mathrm{g} / \mathrm{ml}$ ), Streptococcus agalactiae (MIC of $250 \mu \mathrm{g} / \mathrm{ml}$ ), Propionibacterium acnes (MIC of $125 \mu \mathrm{g} / \mathrm{ml}$ ), Salmonella typhimurium (MIC of 1000 $\mu \mathrm{g} / \mathrm{ml})$. The results showed that the antibacterial property of lectin varies according to the constitution of the bacterial cell wall, EantH can show both bacteriostatic and bactericidal activity [65]. (Siritapetawee and coauthors).

The antibacterial activity of lectin CAL, isolated from Cicer arietinum L., was tested for the pathogenic strains Escherichia coli, Bacillus subtilis, Serratia marcescens and Pseudomonas aeruginosa. CAL showed antimicrobial activity with MICs in the range $80-180 \mu \mathrm{g} / \mathrm{mL}$. The antimicrobial action of lectin is correlated with the peptidoglycan and/or lipopolysaccharide layer of the bacterial cell wall. Muramic acid and the binding affinity of lectin to glycogen can be directly related to antibacterial activity [66].

The development of metallic nanoparticles to fight bacterial infections has been shown to be a potential method, combining copper sulfide nanoparticles (CUS NPs) with Jacalin lectin, isolated from the seeds of Artocarpus heterophyllus. The action efficiency of the Jacalin-CuS NPs complex (JCuS NPs) was evaluated against clinical isolates of methicillin-resistant Staphylococcus aureus (MRSA). The results showed that the JCuS NPs complex promoted the inhibition of MRSA strains and reduced MIC. The mechanical study revealed that the complex exerts bactericidal activity through the recognition of glycans, generating reactive oxygen species and damage to the bacterium's membrane. The results showed that the MIC of CuS NPs after the formation of the complex with jacalin decreases from $12.5 \mu \mathrm{M}$ to $0.78 \mu \mathrm{M}$. The researchers stress that the specificity of lectin by galactose plays a crucial role in the recognition of glycans, providing the site of action for CuS NPs, significantly reducing the required dose of CuS NPs nanoparticles. The antibacterial efficacy of JCuS NPs has been tested and proven in vivo in an animal model of zebrafish [67].

The results with PPL, purified lectin from Parkia platycephala, demonstrated that lectin was able to improve the activity of Gentamicin, an aminoglycoside antibiotic indicated for moderate to severe infections. The action of PPL decreased the MIC of Gentamicin from 32 to $20.2 \mu \mathrm{g} / \mathrm{mL}$ for the E. coli strain, corresponding to a $36.9 \%$ reduction in the amount of antibiotic needed to obtain an effective treatment. Based on these results, the researchers propose that lectin can act by two distinct mechanisms: interacting with Gentamicin in the CRD, facilitating the permeabilization of the antibiotic in the bacterial cytoplasm; or interacting with glycans present in the efflux pump, being responsible for blocking or promoting changes in the conformational structure [68].

The lectin from the roots of Portulaca elatior (PeRoL) has a molecular mass of $33 \mathrm{kDa}$, is composed of two subunits of $15 \mathrm{kDa}$ linked by disulfide bonds. PeRoL has specificity for Galactose, glucose, mannose and N-Acetylglycosamine. The lectin did not show bactericidal activity, however, it obtained bacteriostatic activity against Enterococcus faecalis, Pseudomonas aeruginosa and Staphylococcus aureus [69].

$\mathrm{PgTeL}$ is a lectin extracted from the sarcotest of Punica granatum that showed activity for five isolates of Escherichia coli resistant to drugs capable of producing $\beta$-lactamases, the minimum inhibitory (MIC) and bactericidal (MBC) concentration ranged from 12.5 to $50.0 \mu \mathrm{g} / \mathrm{mL}$ and from 25.0 to $100.0 \mu \mathrm{g} / \mathrm{mL}$, respectively. The effect of $\mathrm{PgTel}$ on the structure of the bacterium was evaluated by three-dimensional images, in all treatments with lectin there was a reduction in the number of cells, a serious change in shape and size was also observed. Lectin also demonstrated antibiofilm activity for all isolates. These data show the importance of PgTeL in the study of lectins with antibacterial capacity, considering that $\beta$-lactam hydrolysis is the most common mechanism for Gram-negative resistance against antibiotics. It was also found that there was a synergistic effect of the combination of PgTeL-ceftazidime for all isolates [70]. $\mathrm{PgTeL}$ also obtained antibiofilm, bacteriostatic and bactericidal activity for methicillin-resistant $S$. aureus, with MIC50 of $12.5 \mu \mathrm{g} / \mathrm{mL}$ and MBC of $50.0 \mu \mathrm{g} / \mathrm{mL}$. Caused changes in the structure and cell viability, the bactericidal activity occurred through injury and death, which occurred mechanism of action against other bacterial strains, as with $E$. coli [71]. 


\section{CONCLUSION}

This review assembled the articles published in the last ten years about the antimicrobial activity of the lectins, describing the different mechanisms of action by which these proteins perform their action in the combat against a wide variety of both Gram-negative and Gram-positive strains. It can be observed that each the plant lectins can act on different types of bacteria with different mechanisms of action from its specificity and distinct from antibiotics. Thus, the importance of this class of proteins is reinforced as a natural alternative for antibacterial resistance. Further studies are required for the occurrence of its clinical application.

Funding: This research received no external funding.

Conflicts of Interest: The authors declare no conflict of interest.

\section{REFERENCES}

1. Gong T, Wang X, Yang Y, Yan Y, Yu C, Zhou R, et al. Plant Lectins Activate the NLRP3 Inflammasome To Promote Inflammatory Disorders. J Immunol. 2017;198:2082-92.

2. Santos AFS, Da Silva MDC, Napoleão TH, Paiva PMG, Correia MTS, Coelho LCBB. Lectins: Function, structure, biological properties and potential applications. Curr Top Pept Protein Res. 2014;15:41-62.

3. Kabir SR, Hasan I, Zubair M. Lectins from Medicinal Plants: Characterizations and Biological Properties. J Funct Foods. 2014; 42:339-56.

4. Van Damme EJM, Lannoo N, Peumans WJ. Chapter 3 Plant Lectins. Adv Bot Res. 2008;48:107-209.

5. Vandenborre G, Smagghe G, Van Damme EJM. Plant lectins as defense proteins against phytophagous insects. Phytochemistry. 2011;72:1538-50.

6. De Vasconcelos MA, Cunha CO, Sousa Arruda FV, Carneiro VA, Mercante FM, Do Nascimento Neto LG, et al. Lectin from canavalia brasiliensis seeds $(\mathrm{ConBr})$ is a valuable biotechnological tool to stimulate the growth of rhizobium tropici in vitro. Molecules. 2012;17:5244-54.

7. De Vasconcelos MA, Cunha CO, Arruda FVS, Carneiro VA, Bastos RM, Mercante FM, et al. Effect of leguminous lectins on the growth of Rhizobium tropici CIAT899. Molecules. 2013;18:5792-803.

8. Laus MC, Logman TJ, Lamers GE, Van Brussel AAN, Carlson RW, Kijne JW. A novel polar surface polysaccharide from Rhizobium leguminosarum binds host plant lectin. Mol Microbiol. 2006;59:1704-13.

9. Lis H, Sharon N. Lectins as Molecules and as Tools. Annu Rev Biochem. 1986;55:35-67.

10. Lacerda RR, Moreira IC, de Lacerda ACS, Cabral NL, Lucetti DL, de Barros Viana GS, et al. Lectin isolated from Brazilian seeds of velvet bean (Mucuna pruriens (L) DC.) presents analgesic, anti-inflammatory and antihemolytic action. J Med Plants Res. 2015; 9(8): 231-42.

11. Leite JFM, Assreuy AMS, Mota MRL, Bringel PHSF, Lacerda RR, Gomes VM, et al. Antinociceptive and antiinflammatory effects of a lectin-like substance from Clitoria fairchildiana R. Howard seeds. Molecules. 2012;17:3277-90.

12. Alencar NMN, Oliveira RSB, Figueiredo JG, Cavalcante IJM, Matos MPV, Cunha FQ, et al. An anti-inflammatory lectin from Luetzelburgia auriculata seeds inhibits adhesion and rolling of leukocytes and modulates histamine and PGE2 action in acute inflammation models. Inflamm Res 2010;59:245-54.

13. Brustein VP, Souza-Araújo FV, Vaz AFM, Araújo RVS, Paiva PMG, Coelho LCBB, et al. A novel antimicrobial lectin from Eugenia malaccensis that stimulates cutaneous healing in mice model. Inflammopharmacology. 2012;20:315-22.

14. Bhutia SK, Behera B, Nandini Das D, Mukhopadhyay S, Sinha N, Panda PK, et al. Abrus agglutinin is a potent anti-proliferative and anti-Angiogenic agent in human breast cancer. Int J Cancer. 2016;139:457-66.

15. Jiang QL, Zhang S, Tian M, Zhang SY, Xie T, Chen DY, et al. Plant lectins, from ancient sugar-binding proteins to emerging anti-cancer drugs in apoptosis and autophagy. Cell Prolif. 2015;48:17-28.

16. Shivamadhu MC, Srinivas BK, Jayarama S, Chandrashekaraiah SA. Anti-cancer and anti-angiogenic effects of partially purified lectin from Praecitrullus fistulosus fruit on in vitro and in vivo model. Biomed Pharmacother. 2017;96:1299-309.

17. Girão DKFB, Cavada BS, De Freitas PA, Martins TV, Franco ÁX, Morais CM, et al. The galactose-binding lectin isolated from Bauhinia bauhinioides Mart seeds inhibits neutrophil rolling and adhesion via primary cytokines. $J$ Mol Recognit. 2015;28:285-92. 
18. De Oliveira SF, Das Neves SP, De Melo CML, Teixeira EH, De Sousa CB, Pereira VAR, et al. Immunostimulatory activity of ConBr: A focus on splenocyte proliferation and proliferative cytokine secretion. Cell Tissue Res. 2011;346:237-44.

19. Da Nóbrega RB, Rocha BAM, Gadelha CAA, Santi-Gadelha T, Pires AF, Assreuy AMS, et al. Structure of Dioclea virgata lectin: Relations between carbohydrate binding site and nitric oxide production. Biochimie. 2012;94(3):900-6.

20. Coelho LCBB, Silva PMDS, Lima VLDM, Pontual EV, Paiva PMG, Napoleão TH, et al. Lectins, Interconnecting Proteins with Biotechnological/ Pharmacological and Therapeutic Applications. Evidence-Based Complement Altern Med. 2017;2017.

21. Procópio TF, de Siqueira PLL, da Silva BBR, de Souza ALM, de Lorena VMB, Paiva PMG, et al. Calliandra surinamensis lectin (CasuL) does not impair the functionality of mice splenocytes, promoting cell signaling and cytokine production. Biomed Pharmacother. 2018;107:650-5.

22. Coelho LCBB, Silva PMS, Silva PMS, Oliveira WF, Moura MC, Pontual EV, et al. Lectins as antimicrobial agentes. Journal of Applied Microbiology. 2018;125:1238-1252.

23. Regente M, Taveira GB, Pinedo M, Elizalde MM, Ticchi AJ, Diz MSS, et al. A sunflower lectin with antifungal properties and putative medical mycology applications. Curr Microbiol. 2014;69:88-95.

24. Ang ASW, Cheung RCF, Dan X, Chan YS, Pan W, Ng TB. Purification and characterization of a glucosaminebinding antifungal lectin from phaseolus vulgaris cv. Chinese Pinto Beans with antiproliferative activity towards nasopharyngeal carcinoma cells. Appl Biochem Biotechnol. 2014;172:672-86.

25. Coutiño-Rodrıguez R, Hernández-Cruz P, Giles-Rıos H. Lectins in fruits having gastrointestinal activity: Their participation in the hemagglutinating property of Escherichia coli 0157:H7. Arch Med Res. 2001;32:251-7.

26. Awoyinka OA, Olajuyigbe $\mathrm{OO}$, Anyasor GN, Osamika $\mathrm{O}$, Adeniyi M. Interaction of lectins isolated from four selected local vegetables on gastrointestinal pathogenic bacteria. Int J Plant Res. 2013;3:67-72.

27. Chrispeels MJ, Raikhel N V. Lectins, lectin genes, and their role in plant defense. Plant Cell 1991;3:1-9.

28. Chatterjee A, Ratner DM, Ryan CM, Johnson PJ, O'Keefe BR, Secor WE, et al. Anti-retroviral lectins have modest effects on adherence of Trichomonas vaginalis to epithelial cells in vitro and on recovery of Tritrichomonas foetus in a mouse vaginal model. PLoS One. 2015;10:1-15.

29. Charungchitrak S, Petsom A, Sangvanich $P$, Karnchanatat A. Antifungal and antibacterial activities of lectin from the seeds of Archidendron jiringa Nielsen. Food Chem. 2011;126:1025-32.

30. Paiva P, Gomes F, Napoleão TH. Antimicrobial activity of secondary metabolites and lectins from plants. Educ Top. 2010:396-406.

31. Drewnowski A, Fulgoni V. Nutrient profiling of foods: Creating a nutrient-rich food index. Nutr Rev. 2008;66:23-39.

32. Vaishnava S, Yamamoto M, Severson KM, Ruhn KA, Yu X, Koren O, et al. The antibacterial lectin Regllly promotes the spatial segregation of microbiota and host in the intestine. Science. 2011;334:255-8.

33. Mukherjee S, Zheng H, Derebe MG, Callenberg KM, Partch CL, Rollins D, et al. Antibacterial membrane attack by a pore-forming intestinal C-type lectin. Nature. 2014;505:103-7.

34. Talas-Oğraş T, Ipekçi Z, Bajroviç K, Gözükirmizi N. Antibacterial activity of seed proteins of Robinia pseudoacacia. Fitoterapia. 2005;76:67-72.

35. Santi-Gadelha T, Gadelha CAA, Aragão KS, de Oliveira CC, Lima MMR, Gomes RC, et al. Purification and biological effects of Araucaria angustifolia (Araucariaceae) seed lectin. Biochem Biophys Res Commun. 2006;350:1050-5.

36. Moura MC, Napoleão TH, Coriolano MC, Paiva PMG, Figueiredo RCBQ, Coelho LCBB. Water-soluble Moringa oleifera lectin interferes with growth, survival and cell permeability of corrosive and pathogenic bacteria. J Appl Microbiol. 2015;119:666-76.

37. Carvalho A de S, da Silva MV, Gomes FS, Paiva PMG, Malafaia CB, da Silva TD, et al. Purification, characterization and antibacterial potential of a lectin isolated from Apuleia leiocarpa seeds. Int $\mathrm{J}$ Biol Macromol. 2015;75:402-8.

38. Gomes FS, Procópio TF, Napoleão TH, Coelho LCBB, Paiva PMG. Antimicrobial lectin from Schinus terebinthifolius leaf. J Appl Microbiol. 2013;114:672-9.

39. Klafke GB, Moreira GMSG, Pereira JL, Oliveira PD, Conceição FR, Lund RG, et al. Lectin I from Bauhinia variegata (BVL-I) expressed by Pichia pastoris inhibits initial adhesion of oral bacteria in vitro. Int $\mathrm{J}$ Biol Macromol. 2016;93:913-8.

40. Waters CM, Bassler BL. Quorum sensing: Cell-to-cell communication in bacteria. Annu Rev Cell Dev Biol. 2005;21:319-46.

41. Ng WL, Bassler BL. Bacterial quorum-sensing network architectures. Annu Rev Genet. 2009;43:197-222. 
42. Silva LN, Zimmer KR, Macedo AJ, Trentin DS. Plant Natural Products Targeting Bacterial Virulence Factors. Chem Rev. 2016;116:9162-236.

43. Brackman G, Coenye T. Quorum Sensing Inhibitors as Anti-Biofilm Agents. Curr Pharm Des. 2014;21:5-11.

44. Cavalcante TTA, Carneiro VA, Neves CC, de Sousa DH, de Queiroz MGM, Arruda FVS, et al. A ConA-like lectin isolated from Canavalia maritima seeds alters the expression of genes related to virulence and biofilm formation in Streptococcus mutans. Adv in Biosc and Biotech. 2013;4(12):1073.

45. Silva AFB, Matos MPV, Ralph MT, Silva DL, De Alencar NM, Ramos MV, et al. Comparison of immunomodulatory properties of mannose-binding lectins from Canavalia brasiliensis and Cratylia argentea in a mice model of Salmonella infection. Int Immunopharmacol. 2016;31:233-8.

46. John B, Rajagopal D, Pashine A, Rath S, George A, Bal V. Role of IL-12-Independent and IL-12-Dependent Pathways in Regulating Generation of the IFN-y Component of T Cell Responses to Salmonella typhimurium. J Immunol. 2002;169:2545-52.

47. Jones BD, Falkow S. Salmonellosis: Host immune responses and bacterial virulence determinants. Annu Rev Immunol. 1996;14:533-61.

48. Lee JY, Kim JY, Lee YG, Byeon SE, Kim BH, Rhee MH, et al. In vitro immunoregulatory effects of Korean mistletoe lectin on functional activation of monocytic and macrophage-like cells. Biol Pharm Bull. 2007;30:204351.

49. O'Neill J. Antimicrobial Resistance: Tackling a crisis for the health and wealth of nations. The Review on Antimicrobial Resistance Chaired. 2014.

50. Founou LL, Founou RC, Essack SY. Antibiotic resistance in the food chain: A developing country-perspective. Front Microbiol. 2016;7:1-19.

51. Rafiq S, Qadir S, Wani IH, Ganie SA, Masood A, Hamid R. Purification and partial characterization of a fructosebinding lectin from the leaves of Euphorbia helioscopia. Pak J Pharm Sci. 2014;27:1805-10.

52. Lerbech AM, Opintan JA, Bekoe SO, Ahiabu MA, Tersbøl BP, Hansen M, et al. Antibiotic exposure in a lowincome country: Screening urine samples for presence of antibiotics and antibiotic resistance in coagulase negative staphylococcal contaminants. PLoS One. 2014;9:1-18.

53. Nygaard R, Romaniuk JAH, Rice DM, Cegelski L. Spectral snapshots of bacterial cell-wall composition and the influence of antibiotics by whole-cell NMR. Biophys J. 2015;108:1380-9.

54. Upadhyay A, Upadhyaya I, Kollanoor-Johny A, Venkitanarayanan K. Combating Pathogenic Microorganisms Using Plant-Derived Antimicrobials: A Minireview of the Mechanistic Basis. Biomed Res Int. 2014;2014.

55. Qadir S, Hussain Wani I, Rafiq S, Ahmad Ganie S, Masood A, Hamid R. Evaluation of antimicrobial activity of a lectin isolated and purified from Indigofera heterantha. Adv Biosci Biotechnol 2013;04:999-1006.

56. Pankey G, Sabath L. Clinical relevance of bacteriostatic versus bactericidal mechanisms of action in the treatment of Gram-positive bacterial infections. Clin Infect Dis. 2004;39:755-6.

57. Nair SS, Madembil NC, Nair P, Raman S, Veerabadrappa SB. Comparative analysis of the antibacterial activity of some phytolectins. Int Curr Pharm J. 2013;2:18-22.

58. Vasconcelos MA, Arruda FVS, Carneiro VA, Silva HC, Nascimento KS, Sampaio AH, et al. Effect of algae and plant lectins on planktonic growth and biofilm formation in clinically relevant bacteria and yeasts. Biomed Res Int. 2014;2014.

59. Moura MC, Trentin DS, Napoleão TH, Primon-Barros M, Xavier US, Carneiro NP, et al. Multi-effect of the water-soluble Moringa oleifera lectin against Serratia marcescens and Bacillus sp.: antibacterial, antibiofilm and anti-adhesive properties. J Appl Microbiol. 2017;123(4):861-74.

60. Pompeu DG, Mattioli MA, Ribeiro RIMA, Gonçalves DB, De Magalhães JT, Marangoni S, et al. Purification, partial characterization and antimicrobial activity of lectin from Chenopodium Quinoa seeds. Food Sci Technol. 2015;35:696-703.

61. Xu P, Zhang T, Guo X, Ma C, Zhang XW. Purification, characterization, and biological activities of broccolini lectin. Biotechnol Prog. 2015;31:736-43.

62. Saha RK, Acharya S, Jamiruddin M, Roy P. Antimicrobial effects of a crude plant lectin isolated from the stem of Tinospora tomentosa 2014.

63. Coriolano MC, Brito JS, Ferreira GRS, Moura MC, Melo CML, Soares AKA, et al. Antibacterial lectin from Moringa oleifera seeds (WSMoL) has differential action on growth, membrane permeability and protease secretory ability of Gram-positive and Gram-negative pathogens. South African J Bot. 2020;129:198-205.

64. Ferreira GRS, Brito JS, Procópio TF, Santos NDL, de Lima BJRC, Coelho LCBB, et al. Antimicrobial potential of Alpinia purpurata lectin (ApuL): Growth inhibitory action, synergistic effects in combination with antibiotics, and antibiofilm activity. Microb Pathog. 2018;124:152-62. 
65. Siritapetawee J, Limphirat W, Wongviriya W, Maneesan J, Samosornsuk W. Isolation and characterization of a galactose-specific lectin $($ EantH) with antimicrobial activity from Euphorbia antiquorum L. latex. Int $J$ Biol Macromol. 2018;120:1846-54.

66. Gautam AK, Gupta N, Narvekar DT, Bhadkariya R, Bhagyawant SS. Characterization of chickpea (Cicer arietinum L.) lectin for biological activity. Physiol Mol Biol Plants. 2018;24:389-97.

67. Ahmed KBA, Subramaniyan SB, Banu SF, Nithyanand P, Veerappan A. Jacalin-copper sulfide nanoparticles complex enhance the antibacterial activity against drug resistant bacteria via cell surface glycan recognition. Colloids Surfaces B Biointerfaces. 2018;163:209-17.

68. Silva RRS, Silva CR, Santos VF, Barbosa CRS, Muniz DF, Santos ALE, et al. Parkia platycephala lectin enhances the antibiotic activity against multi-resistant bacterial strains and inhibits the development of Haemonchus contortus. Microb Pathog. 2019;135:103629.

69. Silva JDF, Silva SP, Silva PM, Vieira AM, Araújo LCC, Lima TA, et al. Portulaca elatior root contains a trehalosebinding lectin with antibacterial and antifungal activities. Int J Biol Macromol 2019;126:291-7.

70. Silva PM, Silva BR, Silva JNO, Moura MC, Soares T, Feitosa APS, et al. Punica granatum sarcotesta lectin (PgTeL) has antibacterial activity and synergistic effects with antibiotics against $\beta$-lactamase-producing Escherichia coli. Int J Biol Macromol. 2019;135:931-9.

71. Silva PM, Baldry M, Peng P, Silva JNO, Soares T, Brayner FA, et al. Punica granatum sarcotesta lectin (PgTeL) impairs growth, structure, viability, aggregation, and biofilm formation ability of Staphylococcus aureus clinical isolates. Int J Biol Macromol. 2019;123:600-8.

() 2021 by the authors. Submitted for possible open access publication under the terms and conditions of the Creative Commons Attribution (CC BY NC) license (https://creativecommons.org/licenses/by-nc/4.0/). 